\title{
FASHIONABLE LEATHER PRODUCTS FROM ECOFRIENDLY DESIGNED VEGETABLE TANNED LEATHERS
}

\author{
ÇEVRE DOSTU TASARIMLI BİTKISEL TABAKLANMIŞ DERILLERDEN \\ MODAYA UYGUN DERİ ÜRÜNLER
}

\section{Selime ÇOLAK ${ }^{*}$ - Fatoş Neslihan ARĞUN ${ }^{* *}$ - Meruyert KAYGUSUZ ${ }^{* * *}$}

\begin{abstract}
Today, due to the increasing demand for sustainable, ecological and original designs and high value-added products, natural dye researchers, engineers, leather and textile designers who use their imagination and creativity are looking for more environmental methods of dyeing and designing of their materials. Surface design and prints on the materials can be done with natural dyes from plants which are abundant in nature. The use of natural dyes has long been known, and they are considered environmentally friendly since obtained from natural sources. In ecological printing, many colorful designs can be obtained naturally on the material surfaces by using flowers, leaves, plant parts etc. There are very few studies regarding the ecological printing on leather and researches in this field are limited and insufficient. In this study, the effect of the use of metal mordant and biomordant on the patterns formed during ecological printing on vegetable tanned leathers was investigated. In addition, the obtained eco-printed leather was used together with a velvet fabric to produce a fashionable design jacket. In addition, a necklace was made from the same ecologically printed leather combined with a chain and peacock feathers, thus demonstrating the usability of ecologically printed leather in the design of various products with different materials. When the results and products obtained in the study are evaluated, the prominent contribution of the study can be revealed as follow; with the surface design made by this method on the leather, there will be no need for chemical dyeing and finishing processes used to color the leather and/or give a pattern to the surface during traditional leather production. The chemicals and dyestuffs used during these processes have adverse effects on both human health and environment. With such practices, it will be possible to reduce or prevent pollution, which is effective on the environment and human health. Furthermore, it is thought that each product designed from eco-printed leather will be attractive to consumers due to the appeal and naturalness of different colors, patterns and shapes that each plant gives to the leather.
\end{abstract}

Keywords: Ecological printing, biological printing, leather, plants, design.

\footnotetext{
* Prof. Dr. - Pamukkale University Denizli Vocational School of Technical Sciences Traditional Handcrafts Department/ Denizli - scolak@pau.edu.tr (Orcid ID: 0000-0002-2371-9523)

** Lecturer - Pamukkale University Denizli Vocational School of Technical Sciences Traditional Handcrafts Department / Denizli - fargun@pau.edu.tr (Orcid ID: 0000-00025626-5935)

*** Doç. Dr. - Pamukkale University Denizli Vocational School of Technical Sciences Textile, Garment, Footwear and Leather Department / Denizli - meruyert_k@hotmail.com (Orcid ID: 0000-0003-2176-7094)
}

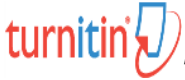

This article was checked by Turnitin. 
ÖZ: Günümüzde sürdürülebilir, ekolojik ve özgün tasarımlar ile katma değeri yüksek ürünlere olan talebin artması nedeniyle, hayal gücünü ve yaratıcılı̆ını kullanan doğal boya araștırmacıları, mühendisler, deri ve tekstil tasarımcıları malzemelerini boyamak ve tasarlamak için daha çevreci yöntemler aramaktadırlar. Doğada bol miktarda bulunan bitkilerden elde edilen doğal boyalar ile malzemeler üzerine yüzey tasarımı ve baskılar yapılabilmektedir. Doğal boyaların kullanımı uzun zamandır bilinmekte olup doğal kaynaklardan elde edildiğinden çevre dostu olarak kabul edilmektedir. Ekolojik baskıda çiçek, yaprak, bitki parçaları vb. kullanılarak malzeme yüzeylerinde doğal olarak birçok renkli tasarımlar elde edilebilmektedir. Deri üzerine ekolojik baskı ile ilgili çok az sayıda çalıșma bulunmakta ve bu konudaki araștırmalar sınırlı ve yetersizdir. Bu çalıșmada, bitkisel tabaklanmış deri üzerine uygulanan ekolojik baskı sırasında, metal mordan ve biomordan kullanımının oluşan desen üzerine etkisi araștırılmıștır. Buna ek olarak, elde edilen eko-baskılı deri, kadife bir kumaşla birlikte kullanılarak modaya uygun tasarım bir ceket üretilmiştir. Ayrıca aynı ekolojik baskılı deriden zincir ve tavus kuşu tüyüyle kombinlenerek bir kolye yapılmış ve böylece, ekolojik baskılı derinin farklı materyallerle, çeşitli ürünlerin tasarımında kullanılabilirliği ortaya konulmuştur. Çalışmada elde edilen sonuçlar ve ürünler değerlendirildiğinde, çalışmanın öne çıkan katkısı şu şekilde ortaya konulabilir; bu yöntemle deri üzerinde yapılan yüzey tasarımı ile geleneksel deri üretimi sırasında deriyi renklendirmek ve/veya yüzeyine desen vermek için kullanılan kimyasal boya ve apre işlemlerine gerek kalmayacaktır. Bu işlemler sırasında kullanılan kimyasallar ve boyarmaddeler hem insan sağlığı hem de çevre üzerindeki olumsuz etkilere sahiptir. Bu tür uygulamalar ile çevre ve insan sağlığı üzerine etkili olan, kirliliğin azaltılması ya da önüne geçilmesi mümkün olacaktır. Üstelik bitkilerin her birinin deriye verdiği farklı renk, desen ve şekillerin çekiciliği ve doğallığı nedeniyle eko baskılı deriden tasarlanan her ürünün tüketiciler için cazip olacağı düşünülmektedir.

Anahtar Kelimeler: Ekolojik baskı, biyolojik baskı, deri, bitkiler, tasarım.

\section{Introduction}

The first thing that attracts attention or affects the consumers in the preference of leather products is color and surface design. In addition, in the fashion industry the added value is only reflected by an efficient surface design. In the process called finishing in leather industry, different patterns can be created on the leather surface with the help of patterned printing rollers (Pop et al., 2019: 3). In dyeing and finishing processes big amount of water and chemicals are used and environmental pollution is increased (Sivaram and Barik, 2019: 55).

With the global warming of the world, to prevent environmental pollution, for a more livable environment, concepts such as sustainable fashion, ecological printing (eco-print), natural dyes, green environment, environmentally friendly designs have gained importance (Öztürk and Yllmaz Ege, 2019: 395). Surface design and prints on the materials can be done with natural dyes which are abundant in nature and easy and cheap to provide.

Introduction of the natural dyeing and ecological printing technique with the application made by India Flint on fabric (Flint, 2008: 78) took an important place in the world textile industry. Ecological printing is a printing 
method that is used to transfer natural colors and shapes to the surface of materials such as fabric, special paper, leather, etc., with materials from nature having colorant features (Çolak et al., 2020: 218). It is the transfer or release of the shapes of plant parts such as leaves, stems, barks, etc. to the fabric by boiling in water (Ismal, 2016: 84).

In ecological printing technique; eucalyptus leaves, maple, sycamore tree, acorn leaf, rose leaf, geranium leaf, basil, mint, fern, calendula flower, lupine, onion peel. olive, pomegranate, lemon, pine tree, fig, maple, bonito, walnut, vine, laurel, black pepper, ornamental plum (Japanese plum), sumac, leaves, branches, root and flowers of pelit plants, alder, apple tree, wild apple leaves and flowers, blueberry, blackberry, marigold, carrot head and root, dahlia, dandelion, iris flower, lilac flower and leaf, oak, pansy, purple cabbage, safflower are used (Bozacl, 2016: 48; Aydoğan Bayram, 2017: 163; Oyman and Can, 2017: 191).

In the ecological printing, plants must be chosen carefully, because some plants are not suitable for due to the release of toxic gases and using plants that are unknown or not identified can also be dangerous. Patterning the fabric surface with completely natural materials can be done with the help of various mordants. Mordants are substances that fix the dyestuff to the substrate, improving color tone and fastness properties (IUPAC, 2019: 2072). Color strength and chromaticity coordinates vary significantly depending on mordant type (Işmal and Ylldırım, 2019: 57). In the ecological printing techniques, mordanting method is generally applied before dyeing process. The most common mordant substances are potassium aluminum sulfate $\left(\mathrm{KAl}\left(\mathrm{SO}_{4}\right)_{3} \cdot 12 \mathrm{H}_{2} \mathrm{O}\right)$, iron sulfate $\left(\mathrm{FeSO}_{4} \cdot 7 \mathrm{H}_{2} \mathrm{O}\right)$ and copper sulfate $\left(\mathrm{CuSO}_{4} \cdot 5 \mathrm{H}_{2} \mathrm{O}\right)$.

In order to minimize the damage caused by metal and other chemical based mordants to the environment, natural mordants called biomordants have come to the fore in recent years (Rather et al., 2016: 3042; Mansour and Heffernan, 2011: 207; Mathur and Gupta, 2003: 90). Biomordants are reported as sustainable and ecologically correct alternatives to metal mordants that provide satisfactory dyeing and durability properties (Bilir, 2018: 66). Especially plants containing tannin or high metal ions in their natural structure are used for mordanting purposes (Vankar et al., 2008: 371).

The oldest and most common type of leather is vegetable tanned leather. Vegetable tanning is a process that utilizes natural plant extracts to treat the leather hides. The result is leather that is generally light tan, beige or light brown in color. After vegetable tanning, leathers become firm, hard and inelastic, and thicker than the chrome tanned leathers. In addition, this type of leathers is hydrophilic, air and water vapor permeable, and biodegradable. The vegetable tanned leathers are commonly used in the manufacture of handbags, luggage, belts, shoes, sneakers, sandals, wallets and personal accessories. 
Although ecological printing on textiles is widely used abroad, there are very few studies regarding ecological printing on leather. The applications on leather are limited to only a few workshop applications, pattern creation and evaluation studies and presentations on conferences (Bozacl, 2016: 22, Sunerli Topan et al., 2019: 63; Çolak et al., 2020: 216). In this study, the effect of metal mordants and biomordant on the ecological printing on vegetable tanned leathers was investigated.

\section{Materials and Method}

\section{Materials}

In ecological printing applications the leaves of the following trees and plants that are widely available have been used: linden, sycamore, ash-leaf maple, read leaf plum, walnut, thuja, rose leaves, poppy flower and nonidentified plant (Fig. 1). Vegetable tanned leathers belonging to the same party were provided. Metal based mordants as potassium aluminum sulfate $\left(\mathrm{KAl}\left(\mathrm{SO}_{4}\right)_{3} .12 \mathrm{H}_{2} \mathrm{O}\right)$, copper sulfate $\left(\mathrm{CuSO}_{4} .5 \mathrm{H}_{2} \mathrm{O}\right)$ and iron sulfate $\left(\mathrm{FeSO}_{4} .7 \mathrm{H}_{2} \mathrm{O}\right)$ and biomordant (spurge plant) were used in the mordanting process. To cover the plants placed on the leathers a cotton fabric was used.
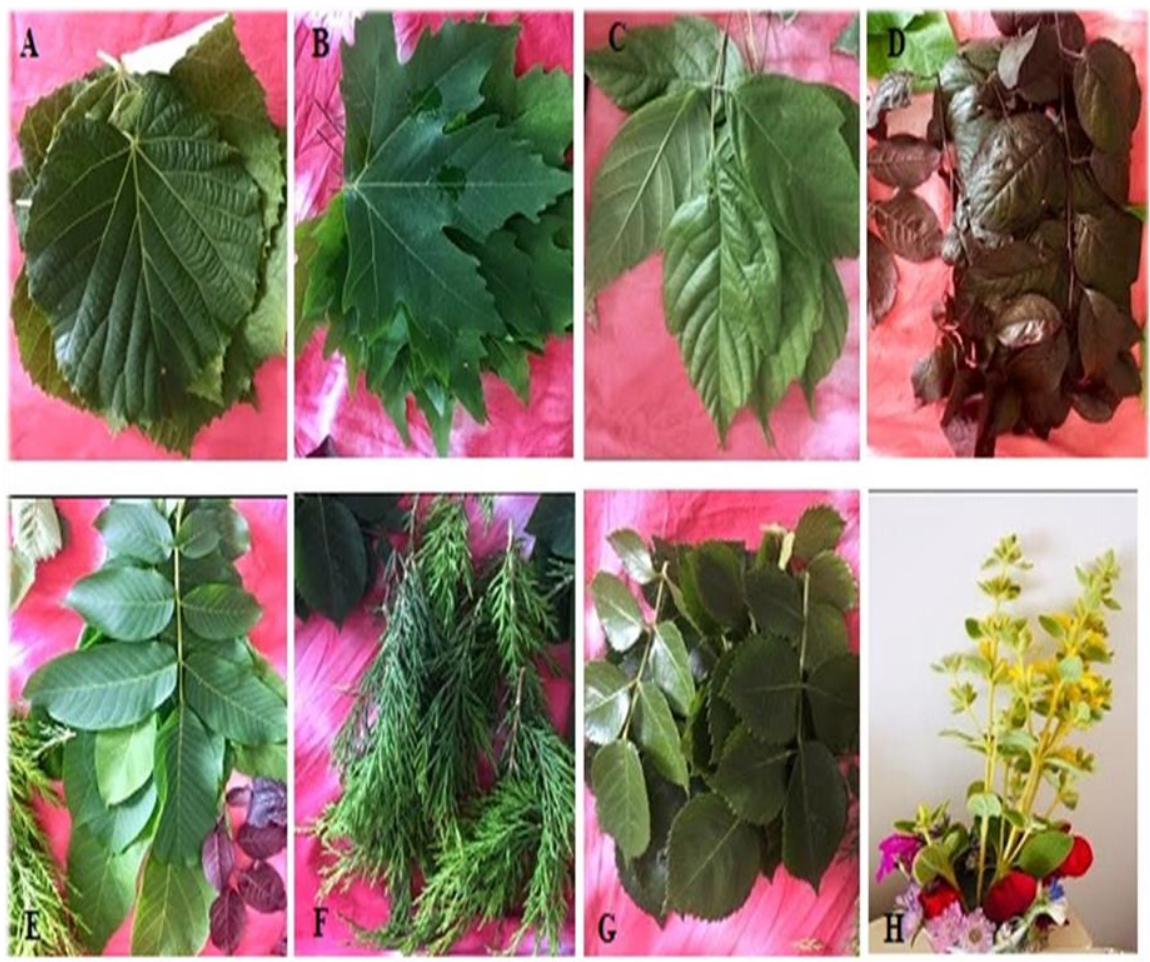


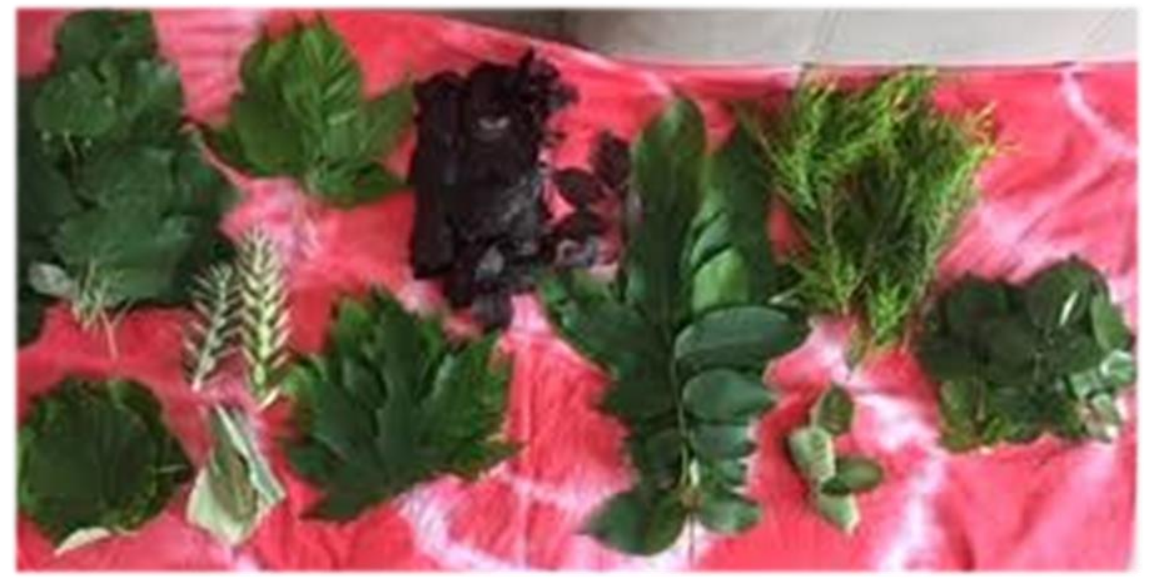

Figure 1. Plants used in the ecological printing applications: linden leaves (A), sycamore leaves (B), ash-leaf maple (C), read leaf plum (D), walnut leaves (E), thuja $(F)$, rose leaves $(G)$, poppy flower and non-identified plant $(H)$, respectively.

\section{Method}

Preparation of mordant solutions: The required amount of iron sulfate $(\% 0.1)$ and copper sulfate $(\% 0.2)$ were weighed and dissolved in 2 liters of warm water. 250 grams of spurge plant (Fig. 2) was weighed and was boiled for $1.5 \mathrm{~h}$ in 2.5 liters of water then filtered. The prepared mordant solutions have been shown in Figure 3.

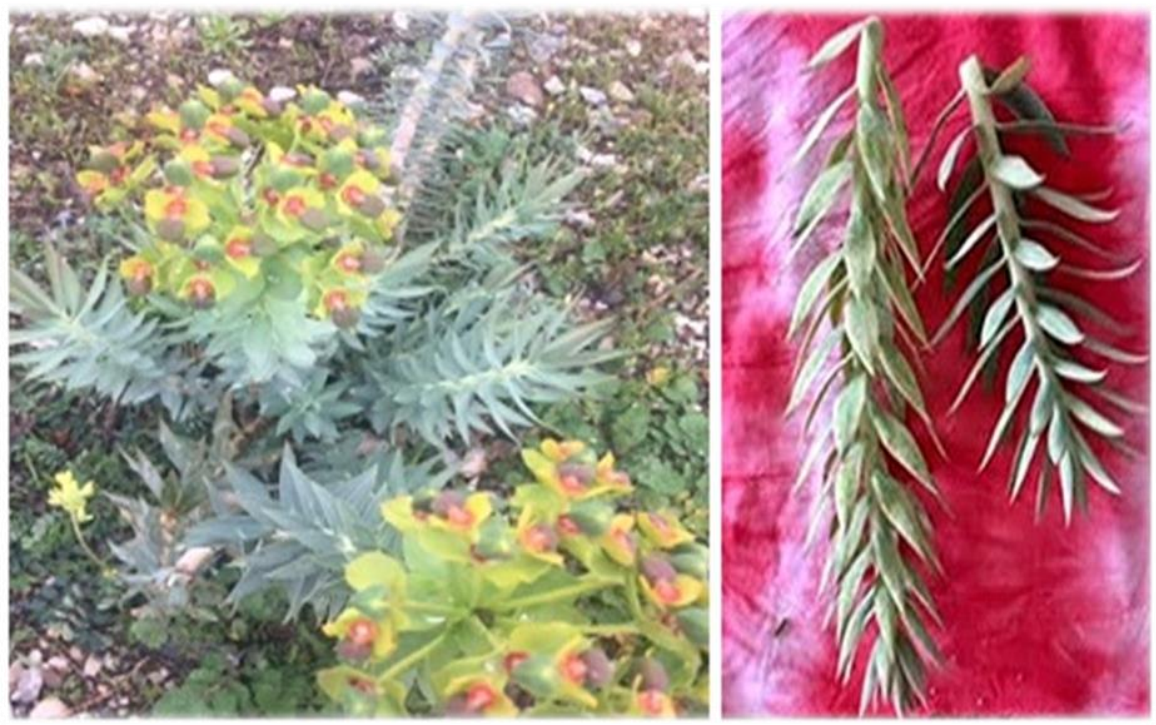

Figure 2. Spurge plant used as biomordant 


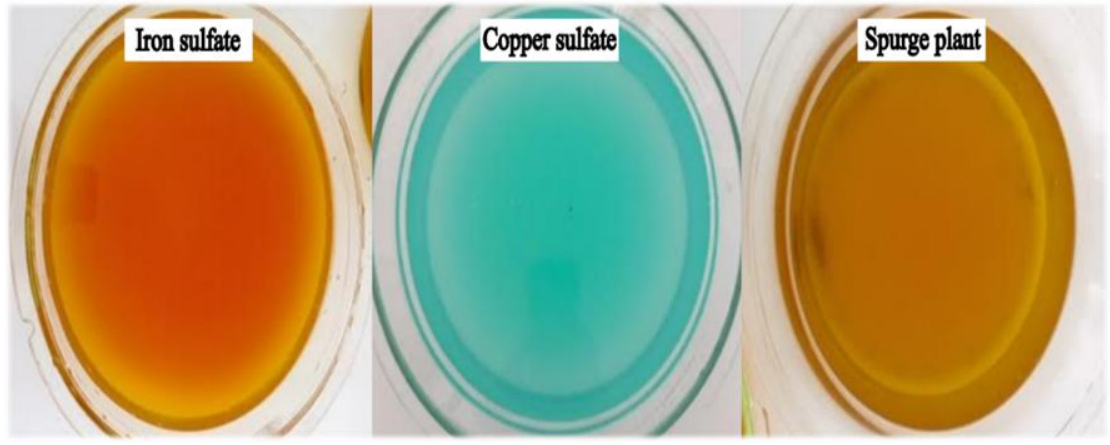

Figure 3. Mordant solutions used in this study

Preparation of leathers: In order to remove unbound tanning agents and other residues and to soak the leather samples were kept in $45^{\circ} \mathrm{C}$ water for 15 minutes. After that, the leather were mordanted in the same bath which contained of $150 \%$ water, $5 \%$ potassium aluminum sulfate, $5 \%$ apple vinegar based on leather weight. $\mathrm{pH}$ of the bath was measured and found as 4.0. The leathers were kept in a mordanting bath for 30 minutes. The cotton blankets were mordanted with iron sulfate.

Mordanting of leaves: Leaves were immersed in the prepared mordant solutions and placed on a paper towel to remove excess mordant solutions. The leaves were kept in a mordant bath for 1-2 minutes.

Ecological printing application: The eco-printing was performed with three separate groups of mordanted leaves. The first group of leaves was mordanted with iron sulfate, the second group with copper sulfate and the third with bio-mordant (spurge) (Fig. 4). The mordanted leaves were placed on leathers and covered by the mordanted cotton blanket. Then the leathers were rolled with a piece of hose and wrapped tightly with nylon then tied and fixed with a rope (Fig. 5). The packaged leather samples were placed in a large pot with water which temperature was kept between $55-60^{\circ} \mathrm{C}$ for 2 hours (Fig. 6).
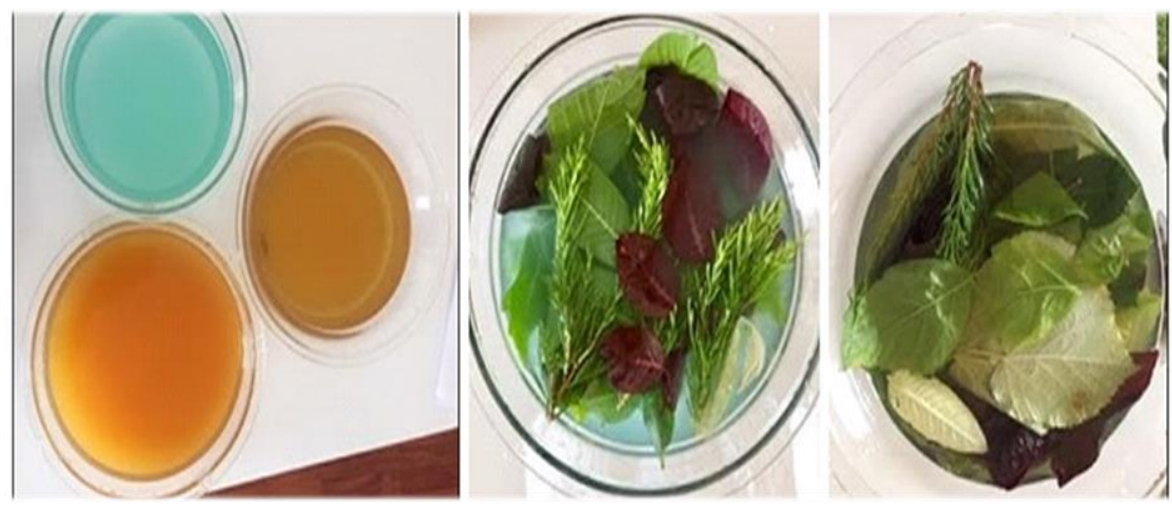

Figure 4. Mordanting of leaves 

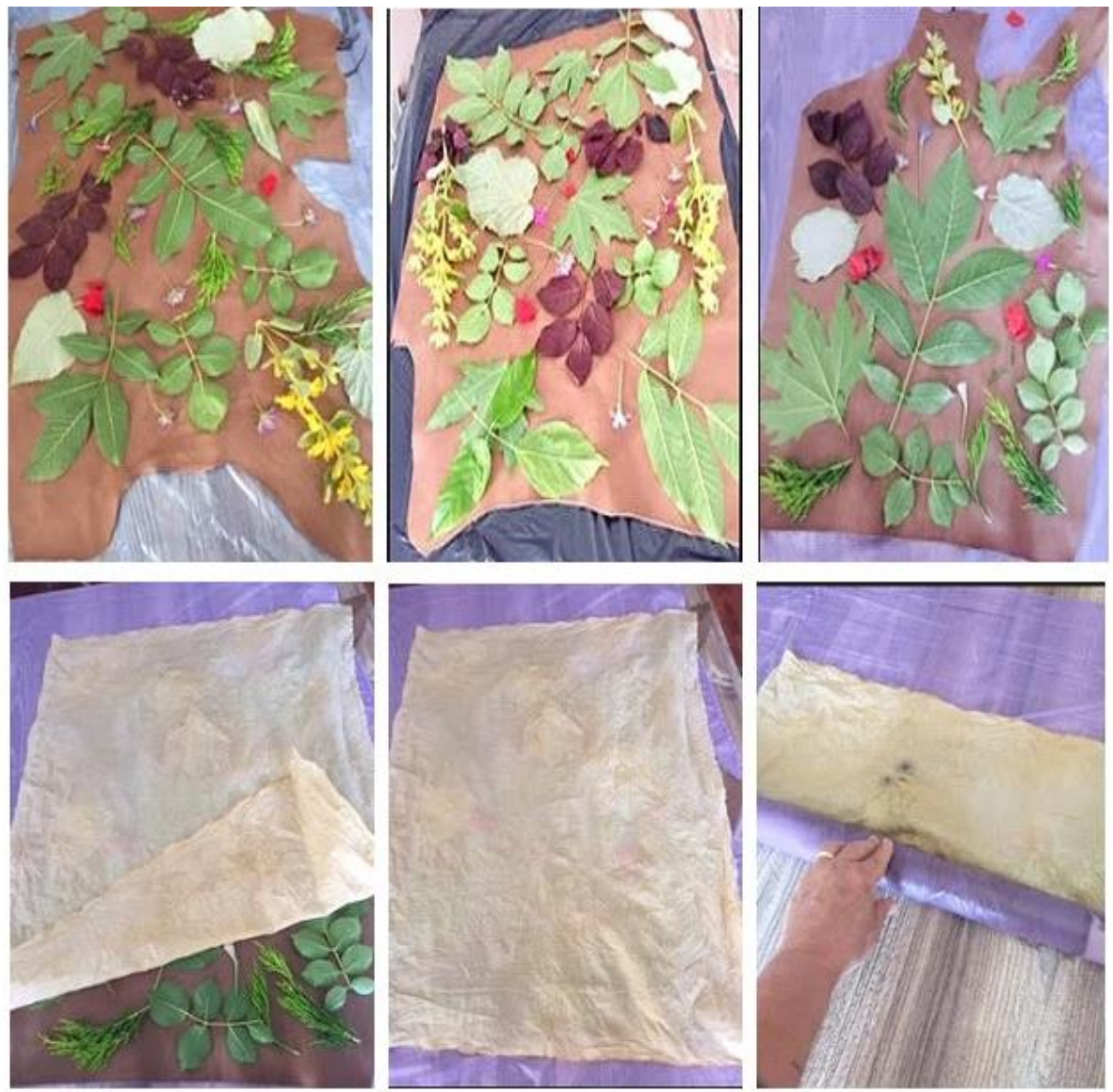

Figure 5. Placing leaves and cotton fabrics on leathers and wrapping them with nylon
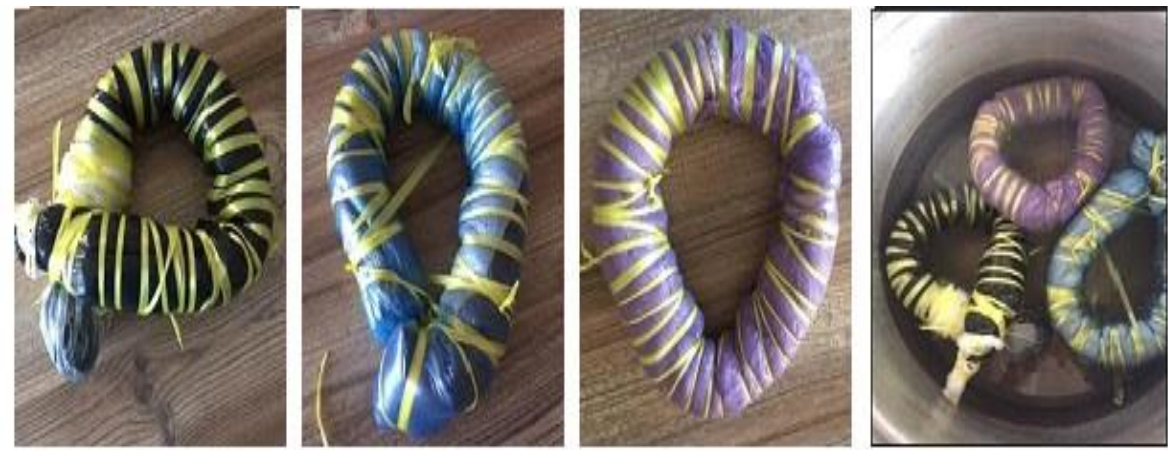

Figure 6. Leather packages and dyeing process

Increase of the temperature may cause shrinkage and deterioration of the leather structure (Çolak et al., 2020: 222). At the end of the process, the leather packages were opened. The leathers should not be immediately kept 
in cold water, because sudden hot and sudden cold may cause roughness of leather structure.

\section{Results and Discussion}

\section{Ecological printing results on leather}

In this study, the effects of various mordant application and fixation techniques on obtaining the impressive patterns, textures and color shades were examined by using vegetable tanned leather. At the end of the ecological printing process, the rolls were taken out of the pot and left for cool. The leathers were opened and the cotton blankets and the herbal wastes on them were removed (Fig. 7). Then the leathers were left to dry completely in a shady and airy place. After drying, the leathers were ironed and the ecological printing process was completed.
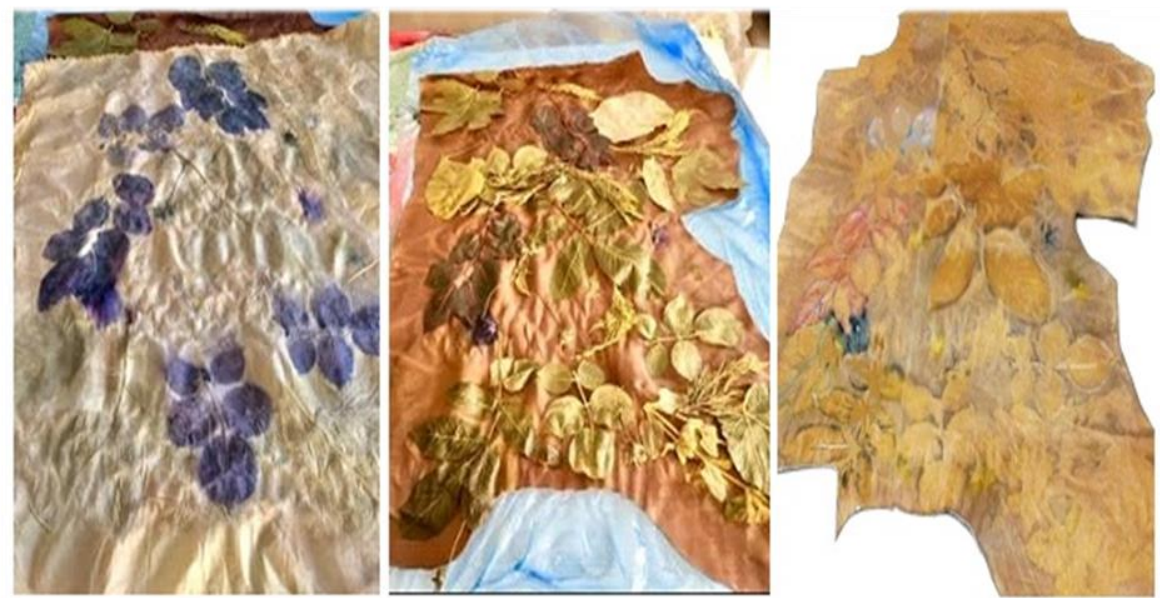

I) Plants were mordanted with iron sulfate
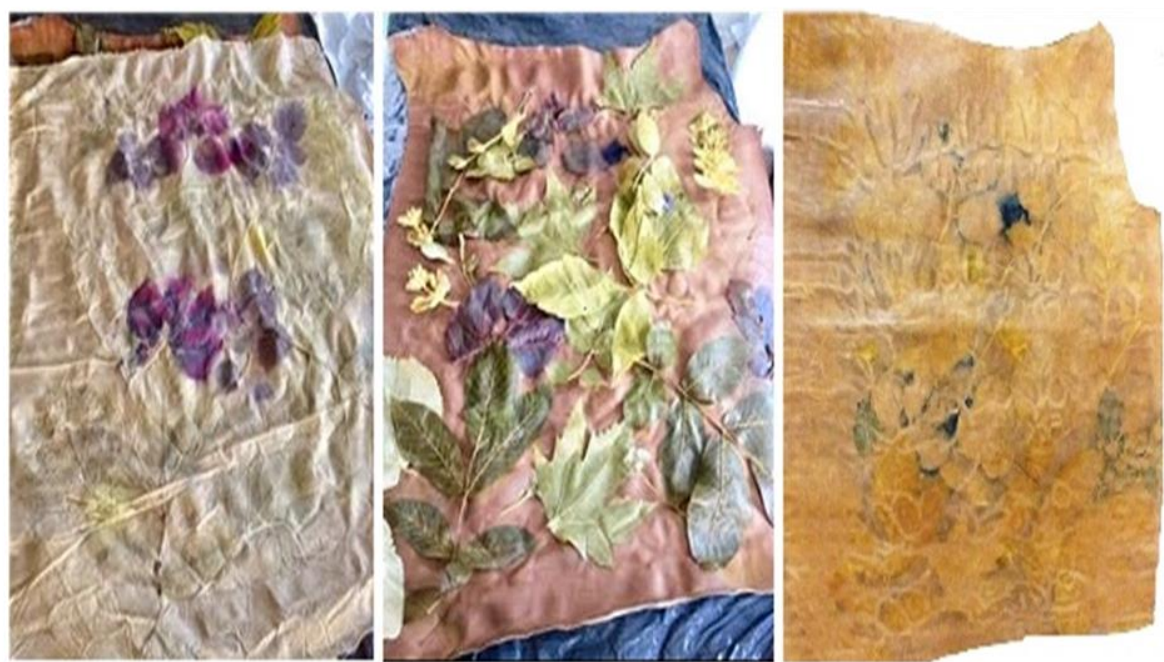
II) Plants were mordanted with copper sulfate
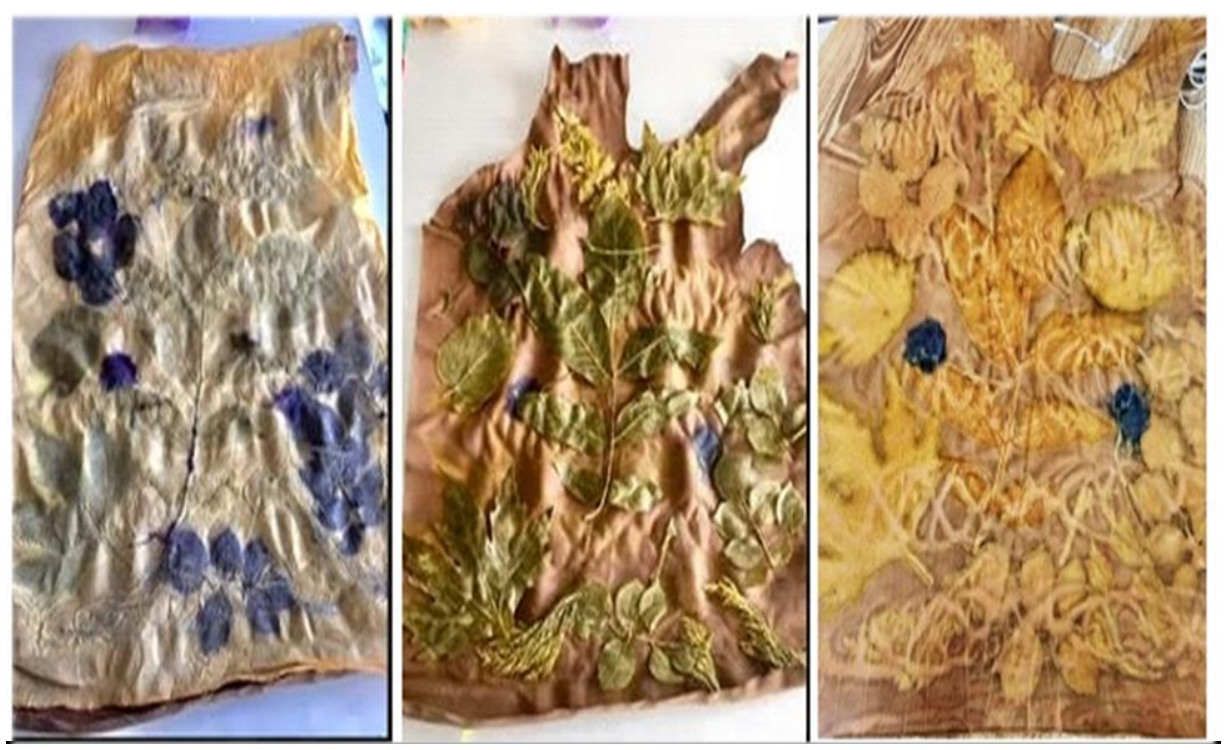

III) Plants were mordanted with biomordant

Figure 7. The eco-print results obtained on the vegetable tanned leathers

The leather images with the eco-print application results are given in Figure 7. When the colors and patterns obtained on the leathers were evaluated, it was seen that the arrangement of various leaves produced different motives. When the different mordants used in the study are evaluated in terms of the patterns and colors they created on the leather, it was observed that the most distinctive patterns and colors were obtained on the leather on which plants were mordanted with spurge or biomordant, followed by the leather on which plants were mordanted with iron sulfate. It has been determined that the patterns formed on the leather with copper sulfate mordanted plants on it and the colors given by the plants are not as distinct as were by other two mordanting methods. The best patterns came from walnut and plane leaves. Rolling bar/hose intensifies the pressure and contact between the plants and the leathers so traces achieved successfully. While the poppy flowers give blue color on the leather, walnut and sycamore leaves give very light green, yellow and brown colors.

When plants were mordanted with metal mordants, patterns were good but only partial colors with blurred effects existed. It was concluded that mordanting with biomordant produced more definite patterns and vivid colors. The detailed patterns and colors obtained on the vegetable tanned leathers with biomordanted plants are presented in Figure 8. 

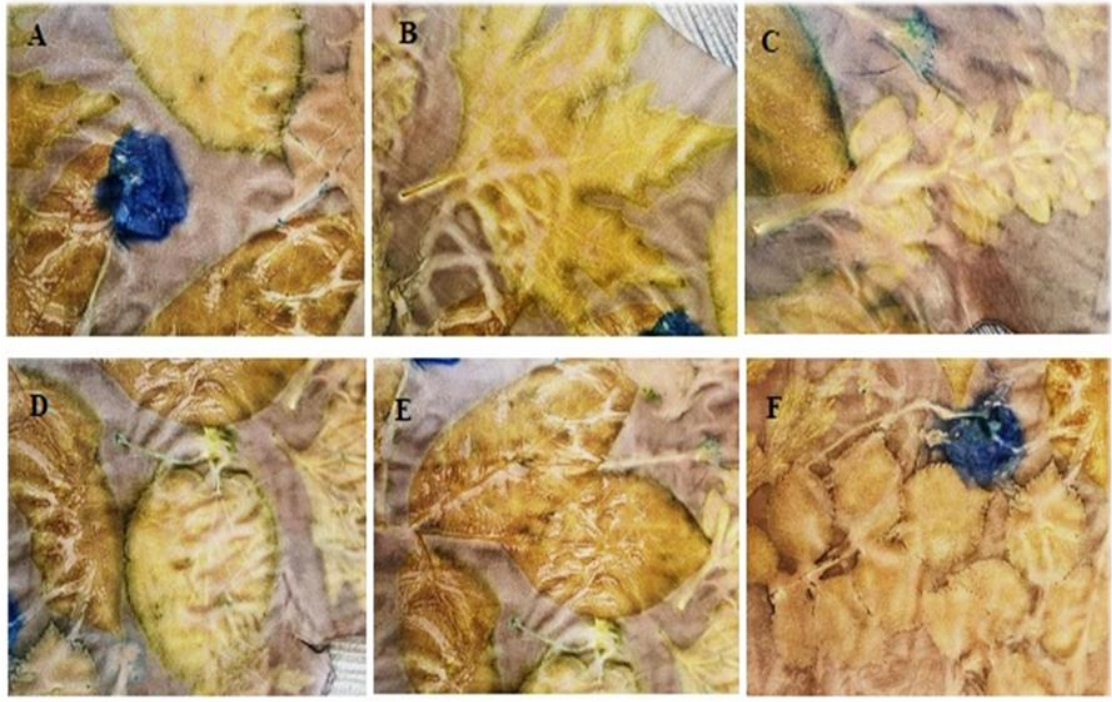

Figure 8. The patterns obtained on the leather with biomordanted plants (poppy flowers (A), sycamore leaves (B), non-identified plant (C), linden leaf (D), walnut leaves $(\mathrm{E})$ and rose leaves $(\mathrm{F})$

\section{Ecological printing results on cotton blanket}

The obtained results of ecological printing on cotton blanket which was used for covering the leathers have been shown in Figure 9. Each used mordant ensures different results. The best patterns and darker colors were achieved by biomordant following by iron sulfate mordanting of plants. With copper mordant relatively lighter/softer colors and patterns were produced. In addition in all three blankets the shapes of all the used leaves appeared to be clear and prominent.

As it was with leathers, different patterns and colors were obtained on the cotton fabrics used as blankets depending on mordanting of the plants. Read plum leaves and rose leaves gave a blue-purple color on the cotton fabrics depending on mordanting. Other plants used have created patterns in light green and yellow colors. When the three mordanting methods are evaluated in terms of colors and patterns on the blankets, it has been revealed that more distinctive patterns and more intense colors are formed on the cotton fabrics, which covered the plants mordanted with spurge and iron sulfate. It was determined that the colors and patterns on the cotton blankets created by plants that were mordanted with iron sulfate were not as good as those that were mordanted with biomordant, but still was better than those obtained from plants mordanted with copper sulfate. In other words, the darkening of the color tones on the cotton blankets according to the way the plants are mordanted was as follows: (from dark to light tones) spurge $>\mathrm{FeSO}_{4}>\mathrm{CuSO}_{4}$. 

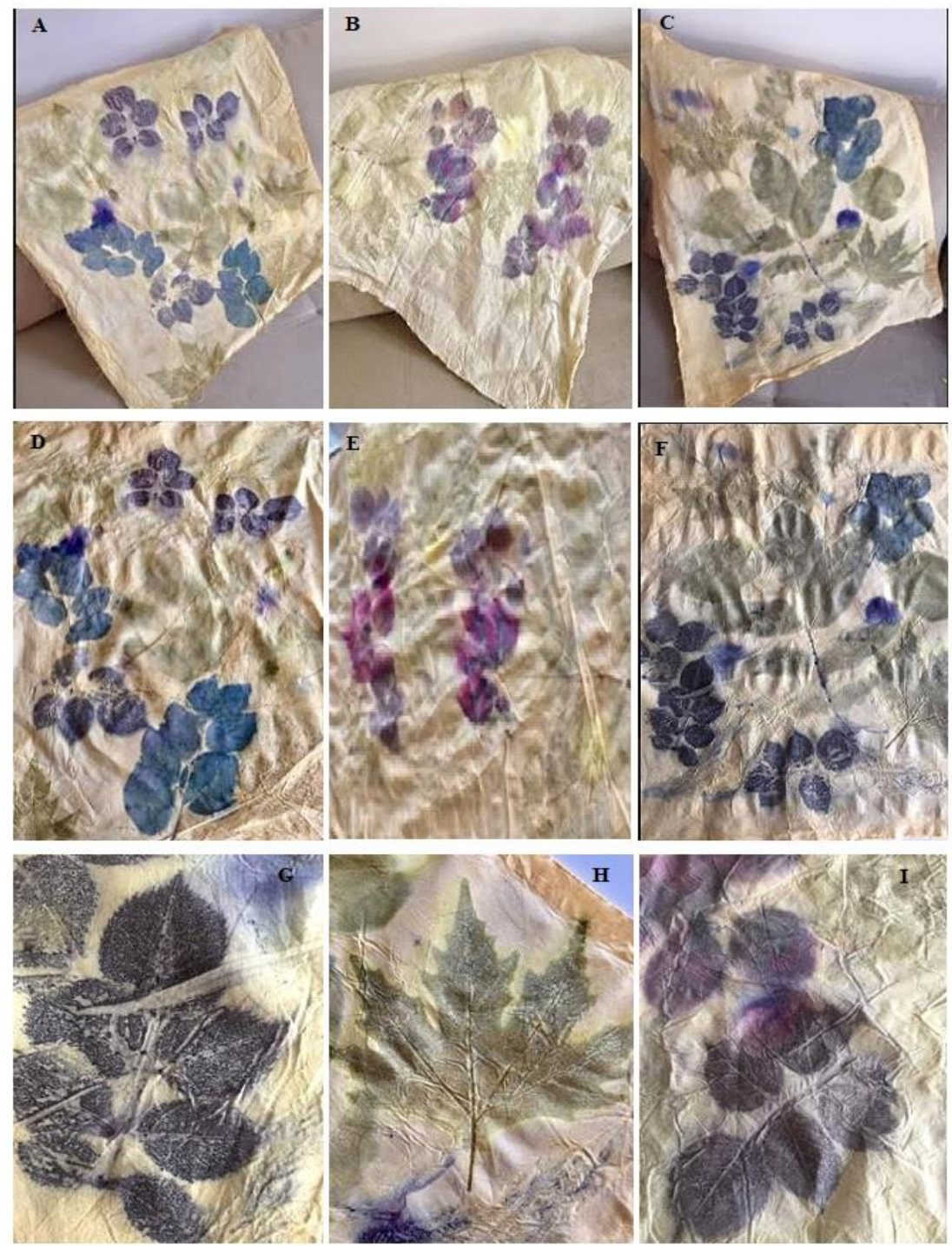

Figure 9. Ecological printing result on the cotton blankets covered plants that mordanted with iron sulfate $(a, d)$, copper sulfate $(b, e)$ and biomordant $(c, f)$ and some close images of patterns ( $\mathrm{g}, \mathrm{h}, \mathrm{i}$ )

Technical knowledge, experience, practice and accurate recipes are the key elements of successful patterns. Even, the change of only one parameter causes significant variation and entirely different unique designs. Ecological printing is a vast and rich application field bringing art and scientific method together in which designers and artist may exhibit their unlimited creativity and imagination (Ismal, 2016: 91).

Many experiments have been made with the ecological printing technique, which is set out by following the dynamics of the society, and this printing technique adorns many items from decorative items to shoes and 
accessories. All the successful results of the trials were transformed into products or designs and shared with fashion followers and customers. In this study eco-printed vegetable tanned leather (biomordanted) is combined with oil green velvet textured fabric for making a jacket. The designed jacket with the eco-printed leather on its back has been presented in Figure 10. The size of the jacket was 38-40. The leather is applied preserving the natural shape of the edge lines in a form in which it is floated from the animal. This natural shape of the leather is beautiful and original in itself. The raw edge flap is uncut and as all hides are unique, it complements the hide's individual characteristics. The patterns of leaves at center were highlighted and marked with silver color stained glass pen. Decorations were made on the front side of the jacket. The necklace using the eco-printed leather was designed with combination of chains and the peacock feather. The accessory was well-matched and accordant to the jacket in terms of the color and structure. The design is unique and exclusive, as the women who will wear it will be also stylish and authentic.
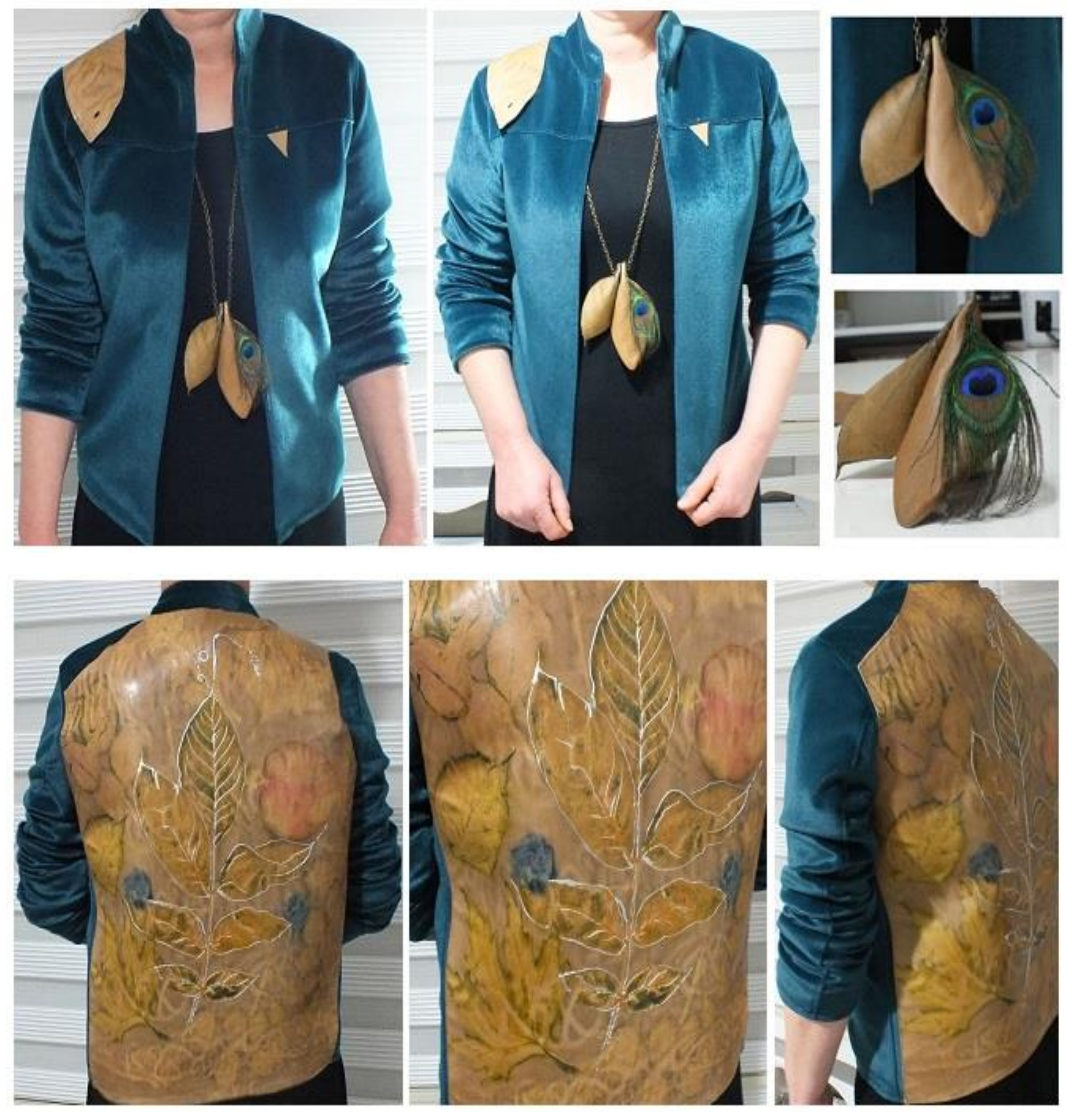


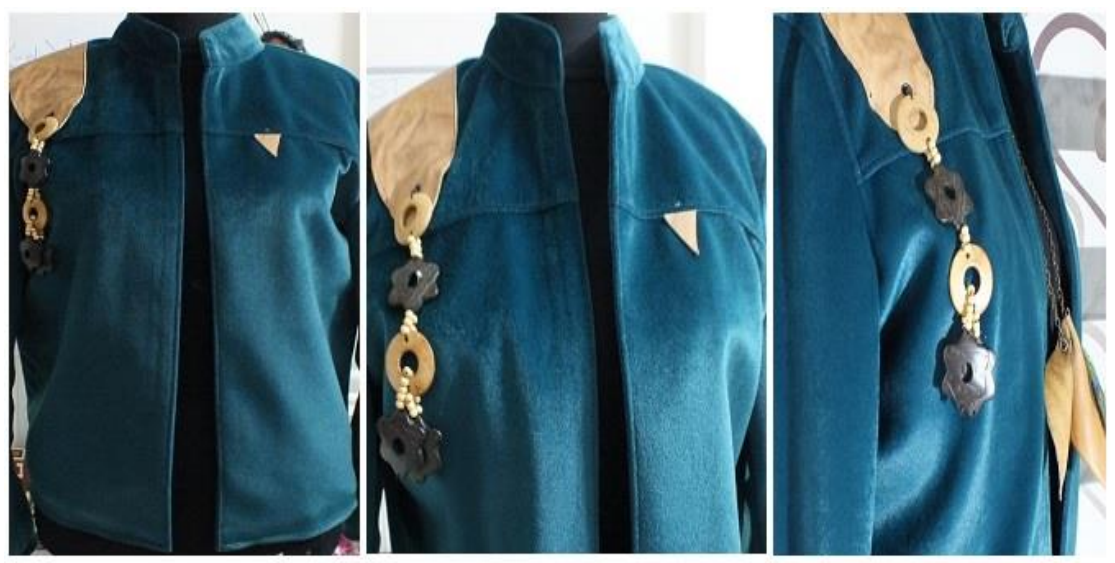

Figure 10. The jacket and necklace designed with the eco-printed leather (designed and photographed by Fatoş Neslihan Arğun, 2021)

The eco-print design products have some advantages as eco-friendly, anti-allergic, good aesthetic appearance and high sales value. However, the main priority advantage of a handmade products is its one and only characteristic; it is exclusive and will not be the same (Nurcahyanti and Septiana, 2018: 400).

According to the results of the study, it has been revealed that the surface design made with plants gives a different appeal to the leather. It is predicted that the use of a natural dyeing method that does not harm people and the environment in leather surface design will contribute to environmentally friendly/ecological fashion. In addition, even if all working conditions are applied in the same way in leather products whose surface design is made with this method, it is not possible to obtain the same pattern design and color. For this reason, it is thought that each product designed may be more attractive for consumers because they are exclusive and unique. Considering the diversity of plants in the world, endless natural pattern options can be emerged.

\section{Conclusions}

Today, the increasing sensitivity and awareness of societies against individual health, nature and environmental pollution has increased immensely. In the study, the effect of the surface design by eco-print method on vegetable tanned leather was examined and two different fashionable products were made from the eco-printed leather: a jacket combined with velvet fabric and a necklace in combination with chains and the peacock feather. When the results obtained are evaluated, the prominent contributions of the study can be listed as follows; with this method, during the production of leather, there will be no need for drum dyeing and finishing processes to color the leather and/or to pattern its surface. Accordingly, it will be possible to prevent negative effects of the chemicals and dyes used during these processes on both human and environment. In 
addition, the surface design made with plants gives a different appeal to the leather from which exclusive and unique fashionable products can be made.

Due to the increasing demand for sustainable, ecological and original designs and high value-added products, natural dye researchers, leather engineers and leather and textile designers/artists who use their imagination and creativity, as well as hobbyists will be able to benefit from the data obtained from this research and add will be able to use this information in the creation of unique and personal designs of high value. In addition, reducing or eliminating the use of metal mordant, which is frequently used in ecological printing, and realizing this technique with more environmentally friendly biomordants will be beneficial in terms of environmental impact.

\section{REFERENCES}

Aydoğan Bayram, M. (2017). Eco printing tekniği ile çevre dostu ekolojik tekstil baskisı. II. Uluslararası Akdeniz Sanat Sempozyumu, 163-170, Antalya: Akdeniz Üniversitesi.

Bilir, M. Z. (2018). Ekolojik boyama esashı çok renkli yüzey tasarımı, Yedi: Sanat, Tasarım ve Bilim Dergisi, S. 20, 63-73.

Bozacı, B. (2016). Doğanın şarkısı ekolojik baskı. İzmir.

Çolak, S. - Arğun, F. N. - Kaygusuz, M. (2020). Ecological printing: Surface design of leathers tanned with different tanning materials. Academic Studies in Engineering II, Ankara: Gece Kitaplığı.

Flint, I. (2008). Botanical eyes for beautiful textiles. USA: Interweave Press.

Ismal Ö. E. (2016). Patterns from nature: Contact printing. Journal of the Textile Association 77(2), 81-91.

Ișmal, Ö. E. - Yıldırım, L. (2019). Metal mordants and biomordants. The Impact and Prospects of Green Chemistry for Textile Technology.

IUPAC, (2019). Compendium of chemical terminology. 2nd ed. (the "Gold Book"). Compiled by A. D. McNaught and A. Wilkinson. Blackwell Scientific Publications, Oxford (1997). Online version (2019) created by S. J. Chalk.

Mansour, H. F. - Heffernan, S. (2011). Environmental aspects on dyeing silk fabric with Sticta coronata lichen using ultrasonic energy and mild mordants. Clean Technol. Envir. Policy, 13, 207-213.

Mathur, J. P. - Gupta, N. P. (2003). Use of natural mordant in dyeing of wool. Indian J. Fibre Text. Res., 3, 90-93.

Nurcahyanti, D. - Septiana, U. (2018). Handmade eco print as a strategy to preserve the originality of Ria Miranda's designs in the digital age. MUDRA Journal of Art and Culture 33(3), 395 - 400.

Oyman, N. R. - Can, D. İ. (2017). Okaliptüs bitkisiyle ipek ve pamuklu kumaş üzerine eko-baskı uygulamaları. II. Uluslararası Akdeniz Sanat Sempozyumu, 191, Antalya: Akdeniz Üniversitesi.

Öztürk, F. - Yılmaz Ege, J. (2019). Sürdürülebilir modanın, ekolojik baskı tekniği ile değerlendirilmesi ve bir örnek uygulama. Avrasya Sosyal ve Ekonomi Araștırmaları Dergisi, 6(5), 394-406. 
Pop M. - Gaidau C. - Niculescu O. - Foiasi T. (2019). Ecology of matter and the surface design in the leather fashion industry. J Textile Sci \& Fashion Tech. 4(1), 1-9.

Rather, L. J. - Shahid-ul-Islama, Shabbira, M. - Bukharia, M. N. - Shahida, M.- Khanb, M. A. - Mohammada, F. (2016). Ecological dyeing of Woolen Yarn with Adhatoda vasica natural dye in the presence of biomordants as an alternative copartner to metal mordants. Journal of Environmental Chemical Engineering, 4, 3041-3049.

Sivaram, N. M. - Barik, D. (2019). Toxic waste from leather industries. Energy from Toxic Organic Waste for Heat and Power Generation, Elsevier Ltd.

Sunerli Topan, E. - Tosun, C. C. - Erol, Ş. - Pamuk, B. - Ürel, S. (2019). Printing experiments on leather surfaces: Ecological printing example. V. International Leather Engineering Congress /Innovative Aspects for Leather Industry, 10-11 October 2019, Izmir.

Vankar, P. S. - Shanker, R. - Dixit, S. - Mahanta, D. - Tiwari, S. C. (2008). Sonicator dyeing of modified cotton, wool and silk with Mahonia napaulensis DC. and identification of the colorant in Mahonia, Ind. Crops Prod. 27, 371-379.

"İyi Yayın Üzerine Kılavuzlar ve Yayın Etiği Komitesi'nin (COPE) Davranış Kuralları" çerçevesinde aşağıdaki beyanlara yer verilmiștir. / The following statements are included within the framework of "Guidelines on Good Publication and the Code of Conduct of the Publication Ethics Committee (COPE)":

İzinler ve Etik Kurul Belgesi/Permissions and Ethics Committee Certificate: Makale konusu ve kapsamı etik kurul onay belgesi gerektirmemektedir. / The subject and scope of the article do not require an ethics committee approval.

Çıkar Çatışması Beyanı/Declaration of Conflicting Interests: Bu makalenin araştırması, yazarlığı veya yayınlanmasıyla ilgili olarak yazarların potansiyel bir çıkar çatışması yoktur. / There is no potential conflict of interest for the author regarding the research, authorship or publication of this article.

Katkı Oranı Beyanı / Author Contributions: Çalışmanın hazırlanması sürecinde yazarlar eşit oranda iş bölümü yapmışlardır. / During the preparation of the study, the authors made an equal division of labor. 